\title{
ACE Inhibitory Activity, Total Phenolic and Flavonoid Content of Watercress (Nasturtium officinale R. Br.) Extract
}

\author{
Catty Amalia Yaricsha, Rissyelly*, Katrin
}

Catty Amalia Yaricsha, Rissyelly*, Katrin

Department of Pharmacognosy-

Phytochemistry, Faculty of Pharmacy, Universitas Indonesia, Kampus Baru UI Depok 16424, Depok, INDONESIA.

\section{Correspondence}

Rissyelly

Department of Pharmacognosy-Phytochemistry, Faculty of Pharmacy, Universitas Indonesia, Kampus Baru UI Depok 16424, Depok, INDONESIA.

Phone: +62 217270031

Email: rissyelly@yahoo.com

\section{History}

- Submission Date: 21-12-2016;

- Review completed: 05-01-2017;

- Accepted Date: 13-01-2017.

DOI : 10.5530pj.2017.2.42

Article Available online

http://www.phcogj.com/v9/i2

\section{Copyright}

(C) 2017 Phcog.Net. This is an openaccess article distributed under the terms of the Creative Commons Attribution 4.0 International license.

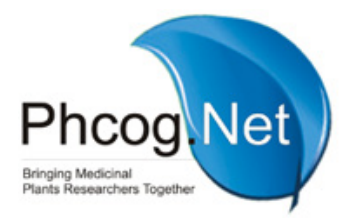

\begin{abstract}
Introduction: Hypertension is the main risk factor for cardiovascular disease. There are many developed antihypertension drugs, one of them is focusing in ACE (Angiotensin Converting Enzyme) inhibition activity. ACE inhibition activity known can decrease vasoconstriction effect and also can decrease bradykinin degradation (vasodilator) by creating NO (nitric oxide). Methods: In this study, we conducted an in vitro ACE inhibition activity test which was obtained from watercress on $70 \%$ ethanolic extract and each fraction (n-hexane, ethyl acetate, and n-butanol). Results: Results of the study showed that ethanolic extract of watercress had ACE activity with $I C_{50}$ value was $19.05 \mu \mathrm{g} / \mathrm{mL}$ and the highest $I C_{50}$ of each fraction is ethyl acetate with $I C_{50}$ value was $2,303 \mu \mathrm{g} /$ $\mathrm{mL}$. n-butanol fraction had the highest total phenolic content with $15.798 \mathrm{mg}$ GAE/g of the extract, while the highest total flavonoid content was obtained on ethyl acetate fraction with $82.847 \mathrm{mg} \mathrm{OE} / \mathrm{g}$ of the extract. Conclusion: The results suggest that Watercress (Nasturtium officinale R. Br.) possess ACE inhibitory activity. Key words: ACE inhibitor, flavonoid, Watercress (Nasturtium officinale R. Br.), phenolic.
\end{abstract}

\section{INTRODUCTION}

Hypertension is the biggest challenge in Indonesia. Based on Riset Kesehatan Dasar data on 2013, there was quite high hypertension prevalence, which was shown as $25.8 \%$. Every year, hypertension has caused the death of 9.4 million people. WHO predicted that in 2025 there will be around $29 \%$ of world population that suffered from hypertension and will increase if they don't follow a healthy lifestyle. The highest percentage of hypertension now obtained from development countries.

Based on clinical studies, antihypertension drugs such as Angiotensin Converting Enzyme inhibitor (ACEi), Angiotensin Receptor Blocker (ARB), betablocker (BB), Calcium Channel Blocker (CCB), and thiazide diuretics can lower hypertension complications without affecting the target organs. ${ }^{2}$

The raise of blood pressure can be caused by the lowering effect of peripheral pressure. NO (Nitric Oxide) is a vasodilator agent works by lowering the peripheral pressure. ACE (Angiotensin Converting Enzyme) inhibition works by inhibiting the production of Angiotensin II and increase bradykinin level. Bradykinin induces receptor on endothelial cells and causing NOS3 (Nitrate Oxide Synthase 3) activation, NOS3 (endothelial) can convert arginine into $\mathrm{NO}$ and produce vasodilatation effect. Watercress (Nasturtium officinale $\mathrm{R}$. Br.) is a widely consumed plant by the population. This plant usually used as food, while many people also use them as traditional medicine. Watercress (N. officinale R. Br.) known has ACE inhibition activity, this is shown with IC50 value of the methanolic extract of $\mathrm{N}$. officinale $\mathrm{R}$. Br. which is $15.40 \mu \mathrm{g} / \mathrm{mL}$ and contained alkaloid, saponin, $_{3}$ anthraquinone, terpenoid, and tannin compounds.

On this study, we conducted ACE inhibition activity test which was obtained from watercress (Nasturtium officinale $\mathrm{R}$. Br.), continued with each fraction (n-hexane, ethyl acetate, and n-butanol) and also a measurement of total phenolic content and total flavonoid content.

\section{MATERIALS AND METHODS}

This study was conducted in Phytochemical Laboratory and Quantitative Analysis of Pharmaceutical Chemistry of the Universitas Indonesia, Depok. Work procedures done were material preparations, extractions, fractionations, ACE inhibition percentage measurements and IC50 test from the extract and also total phenolic and flavonoid content measurements on watercress (Nasturtium officinale R. Br.) fractions.

\section{Material Preparations}

Plant determination was conducted to confirm that we used the right plant, such as watercress (Nasturtium officinale R. Br.). Plant identification result showed that sample was in Brassicaceae Family, Nasturtium officinale R. Br. Species.

\section{Botanical Extraction}

The method used in extraction process in this study was maceration with ethanol $70 \%$ as the solvent, aiming to separate some secondary metabolites in the botanical powder. Maceration method was chosen because the device was simple and safe to use for thermolabile compounds because this method does not need heat. 
Maceration was conducted by soaking the botanical powder which had been put in a cloth soaked with $2.5 \mathrm{~L}$ ethanol $70 \%$ solvent for $2 \times 24$ hours and stirred for every one hour until the first six hours reached, remaceration was conducted to ensure that the chemical compounds contained in the study plant wsere separated completely. Remaceration process was conducted until 7 times, then the macerate was collected and separated using filter papers to prevent filtrate to be mixed with the lees, then the filtrate was evaporated using evaporator device on $55^{\circ} \mathrm{C}$ with $50 \mathrm{rpm}$ rate until obtained a condensed extract. After evaporation process, we obtained a condensed extract of watercress plant ( Nasturtium officinale $\mathrm{R}$. Br.) as much as 124.2 grams, then we measured the dissolved compounds in the solvent which was used to obtain the yield. The yield of watercress condensed extract (Nasturtium officinale R. Br.) was $24.84 \%$.

\section{Fractionation}

In this study, fractionation was conducted with 50.13 grams extract on n-hexane (non-polar), ethyl acetate (semi-polar), and n-butanol (polar) as the solvent. The raised polarity properties of the solvent used wsere done so that the compounds in the botanical can be extracted and separated based on the polarity properties of the compounds. Each fraction yields obtained from n-hexane, ethyl acetate and n-butanol were 3.591, 3.271 , and $7.341 \%$. The final yield of the fractionation process was in the water phase.

\section{RESULTS AND DISCUSSIONS}

\section{ACE Inhibition Activity Test}

The in vitro ACE inhibition activity test of watercress (Nasturtium officinale R. Br.) was measured using ACE Kit-WST (Dojindo, Japan) because of the fast, accurate, and specific process. The main principle of the study using this method is measuring $3 \mathrm{HB}$ (3-hydroxybutyrate) absorption obtained from the ACE catalyzation process towards $2 \mathrm{HB}$ GGG and WST-1 formazan substrates.

Results of the study toward the inhibition value of watercress were $94.31 \%$, then on the sample extract, we measured the $\mathrm{IC}_{50}$ values in five various final concentration, such as $100.5,50.25,25.13,12.56$, and 6.28 $\mu \mathrm{g} / \mathrm{mL} . \mathrm{IC}_{50}$ value of the ethanolic extract of watercress obtained was $19.05 \mu \mathrm{g} / \mathrm{mL}$. The result could be found below. Data of ACE inhibition activity in $70 \%$ ethanolic extract cand be found in Table 1

This study was compared with captopril as the standard of ACE inhibition activity and the percentage value of ACE activity obtained was $34.34 \%$ on $5 \times 10-8$ ppm, this showed that watercress (Nasturtium officinale $\mathrm{R}$. Br.) provide ACE inhibition activity, but lower than captopril because in the botanical powder still contained other chemical compounds, while captopril is a pure compound.

Then ACE inhibition activity was test in each fractions (n-hexane, ethyl acetate, n- butanol) and the result was 71,31\% (100 $\mu \mathrm{g} / \mathrm{mL}) ; 75,74 \%(50$ $\mu \mathrm{g} / \mathrm{mL}) ; 78,78 \%(100 \mu \mathrm{g} / \mathrm{mL})$ respectively. The highest inhibition value obtained in ethyl acetate fraction with $\mathrm{IC}_{50}$ was $2,303 \mu \mathrm{g} / \mathrm{mL}$. IC $\mathrm{I}_{50}$ ethyl acetate could be found in Table 2 .

$\mathrm{IC}_{50}$ curve of ethyl acetate fraction of Watercress can be found in Figure 1 and data of ACE inhibition activity in ethyl acetate fraction can be found in Table 2 .

\section{Total Phenolic Content Measurement}

Total phenolic content of watercress fractions was measured using FolinCiocalteu method. Folin-Ciocalteu reagent was used as color complex because a reaction between gallic acid and Folin-Ciocalteu can form a stable complex with blue colored. The denser the colour means the high- er the phenolic ion contained in the sample solutions. Phenolic concentration data from each watercress (Nasturtium officinale $\mathrm{R}$. Br.) fraction shown in the Table 3

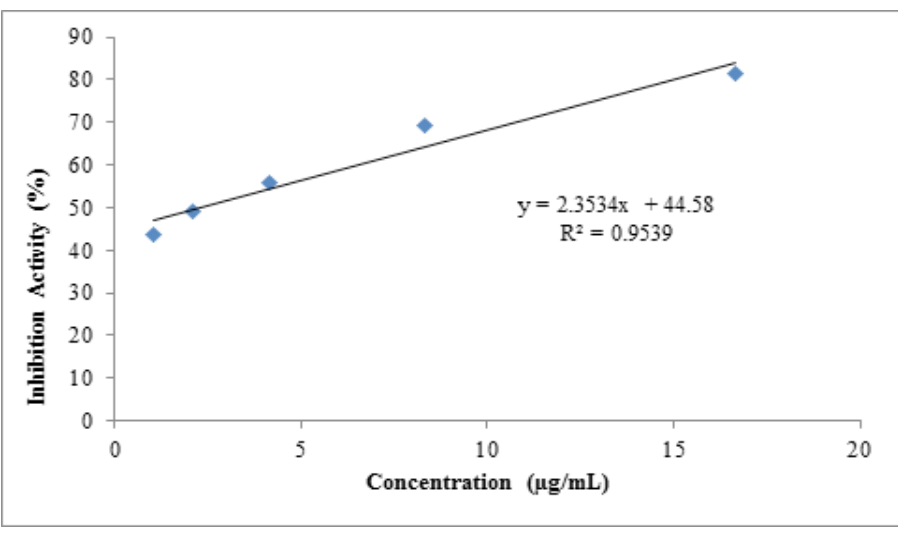

Figure 1: IC $C_{50}$ curve of ethyl acetate fraction of Watercress.

Table 1: ACE inhibition activity in $\mathbf{7 0} \%$ ethanolic extract of Watercress.

\begin{tabular}{cccc}
\hline Sample & $\begin{array}{c}\text { Concentration } \\
(\mu \mathrm{g} / \mathrm{mL})\end{array}$ & $\begin{array}{c}\text { Inhibition } \\
(\%)\end{array}$ & IC50 $(\mu \mathrm{g} / \mathrm{mL})$ \\
\hline & 33,33 & 62,65 & 19,05 \\
& 16,75 & 47,45 & \\
Watercress & 8,37 & 39,48 & \\
ethanolic extract & 4,19 & 37,52 & \\
& 2,09 & 36,78 & \\
\hline
\end{tabular}

Table 2: ACE inhibition activity in ethyl acetate fraction of Watercress.

\begin{tabular}{cccc}
\hline Sample & $\begin{array}{c}\text { Concentration } \\
(\mu \mathrm{g} / \mathrm{mL})\end{array}$ & $\begin{array}{c}\text { Inhibition } \\
(\%)\end{array}$ & $\mathrm{IC}_{50}(\mu \mathrm{g} / \mathrm{mL})$ \\
\hline & 16,67 & 81,287 & 2,303 \\
Ethyl Acetate fraction & 8,33 & 69,049 & \\
& 4,17 & 55,750 & \\
& 2,08 & 49,144 & \\
& 1,04 & 43,662 & \\
\hline
\end{tabular}

Table 3: Phenolic concentration data of watercress fractions

\begin{tabular}{ccc}
\hline $\begin{array}{c}\text { Fraction } \\
\text { Sample }\end{array}$ & $\begin{array}{c}\text { Average C } \\
(\mathrm{mg} / \mathrm{L})\end{array}$ & $\begin{array}{c}\text { Phenolic Concentration }(\mathrm{mg} \\
\mathrm{GAE} / \mathrm{g})\end{array}$ \\
\hline n-hexane & 6.442 & $0.739 \pm 0.14$ \\
Ethyl acetate & 1.414 & $1.469 \pm 0.01$ \\
n-butanol & 6.207 & $3.624 \pm 0.13$ \\
\hline
\end{tabular}

Table 4: Flavonoid concentration data of watercress fractions

\begin{tabular}{ccc}
$\begin{array}{c}\text { Fraction } \\
\text { Sample }\end{array}$ & $\begin{array}{c}\text { Average C } \\
(\mathrm{mg} / \mathrm{L})\end{array}$ & $\begin{array}{c}\text { Phenolic Concentration (mg } \\
\text { GAE/g) }\end{array}$ \\
\hline n-hexane & 11.22 & $2.011 \pm 0.023$ \\
Ethyl acetate & 4.17 & $2.701 \pm 0.013$ \\
n-butanol & 10.01 & $1.462 \pm 0.101$ \\
\hline
\end{tabular}




\section{Total Flavonoid Content Measurement}

Total flavonoid content of watercress fractions was measured using aluminum chloride colorimetry method. ${ }^{(4,5)}$ The measurement principle was $\mathrm{AlCl}_{3}$ which form an acid resistance complex containing keto group on $\mathrm{C} 4$ and hydroxyl groups on $\mathrm{C} 3 \mathrm{\&} \mathrm{C} 5$, also can form an acid resistance complex containing ortho hydroxy on flavonoid $\mathrm{B}$ ring. The result of the measurement then compared with absorption curve of the comparison, which is quercetin. Quercetin was chosen because this compound is the most flavonoid available in the plants. Flavonoid concentration data from each watercress (Nasturtium officinale R. Br.) fraction shown in the Table below:

The results obtained were varied, ethyl acetate fractions had the highest total flavonoid content compared with other fractions, and these showed that compounds in ethyl acetate fraction could be aglycon compound or flavonoid with one or two sugars. Order from the highest to the lowest was ethyl acetate fraction $>$ n-hexane fraction $>$ n-butanol fraction. The order of flavonoid content not always similar with the phenolic content. This could happen because, on total phenolic content measurement, almost all phenolic groups such as a flavonoid, tannin, anthocyanin, and simple phenol would all be measured therefore there was a possibility if flavonoid was not the highest content in watercress (Nasturtium officinale R. Br.). Like the obtained sample, n-butanol fraction has the highest total phenolic content compared with other fractions while the flavonoid content in n-butanol fraction had the lowest value.

\section{CONCLUSIONS}

Based on the test result, we concluded that: Watercress (Nasturtium officinale $\mathrm{R}$. Br.) in ethanolic extract 70\% provide Angiotensin Converting Enzyme (ACE) inhibition with $\mathrm{IC}_{50}$ value was $19.05 \mu \mathrm{g} / \mathrm{mL}$. Watercress
(Nasturtium officinale R. Br.) in ethyl acetate fraction provide Angiotensin Converting Enzyme (ACE) inhibition with $\mathrm{IC}_{50}$ value was 2.303 $\mu \mathrm{g} / \mathrm{mL}$. Watercress (Nasturtium officinale R. Br.) ethyl acetate fraction had the highest antioxidant activity with $\mathrm{EC}_{50}$ value was $18.816 \mu \mathrm{g} / \mathrm{mL}$. Watercress (Nasturtium officinale R. Br.) n-butanol fraction had total phenolic content value on $3.624 \mathrm{mg} \mathrm{QE} / \mathrm{g}$ extract and ethyl acetate fraction with the highest total flavonoid content with $2.710 \mathrm{mg}$ QE/g extract.

\section{ACKNOWLEDGEMENT}

This study was supported by The Directorate of Research and Community Engagement Universitas Indonesia via Hibah PITTA 2016.

\section{CONFLICT OF INTEREST}

All co-authors have seen and agree with the contents of the manuscript and there is no financial interest to report. We certify that the submission is original work and is not under review at any other publication.

\section{ABBREVIATIONS USED}

ACE: Angiotensin Converting Enzyme; $\mathrm{IC}_{50}$ : Inhibition Concentration at 50\%; GAE: Gallat Acid Equivalent; QE: Quercetine Equivalent.

\section{REFERENCES}

1. World Health Organization, 2010, Data Global Status Report on Communicable Diseases. WHO Press.

2. Seventh report of the Joint National Committee on prevention, detection, evaluation, and treatment of high blood pressure, USA: Department of Health and Human Services. 2003

3. Saputri FC, Mun'im A, Lukmanto D, Aisyah SN, Rinandy JS, Inhibition of Angiotensin Converting Enzyme (ACE) Activity by some Indonesia Edible Plants. Depok: IJPSR. 2015;6(3):1054-9.

4. Chang C, Yang M, Wen H, Chern J, Estimation of total flavonoid content in propolis by two complementary colorimetric methods. Journal of Food Drug

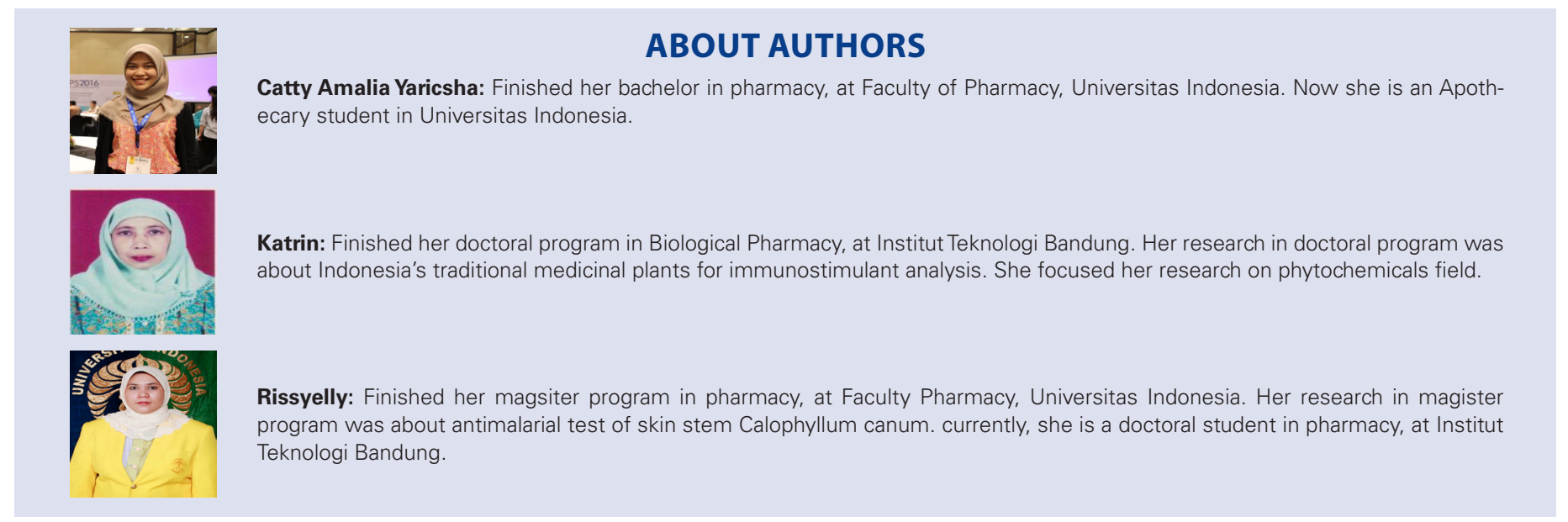

Cite this Article: Yaricsha CA, Rissyelly, Katrin. ACE Inhibitory Activity, Total Phenolic and Flavonoid Content of Watercress (Nasturtium officinale R. Br.) Extract. Pharmacogn J. 2017;9(2):249-51. 